Anna TIIDO

University of Warsaw

\title{
THE „RUSSIAN WORLD”: THE BLURRED NOTION OF PROTECTING RUSSIANS ABROAD
}

\begin{abstract}
T
he purpose of this article is to see into the ambigous phenomenon of the "Russian World" in connection to the role of this concept in securitising the Russian minorities abroad. I will look into the problem using the scheme developed by Rogers Brubaker ${ }^{2}$ complemented by other researchers and the securitisation theory of the Copenhagen school. This combination provides us with the valuable insight into the relationships between the host states, external national homelands, national minorities and international organisations. In this article, I will concentrate on the external national homeland, in our case, Russia.

As I mentioned above, I base myself on the Brubaker model of triadic axis, the relationship between the national minority, host-state, and external national homeland. In addition, I, following several authors, add another dimension to it, meaning the role of international organizations. Thus, the quadratic relationship is formed. I dare name this forth factor "the Collective West" for the analytical purposes. I also add another dimension, that
\end{abstract}

\footnotetext{
${ }^{1}$ Instytut Stosunków Międzynarodowych, Wydział Nauk Politycznych i Studiów Międzynarodowych, Uniwersytet Warszawski.

2 R. Brubaker, Nationalism Reframed. Nationhood and the national question in the New Europe, Cambridge University Press, Cambridge 1996.
} 
of securitisation, following the authors of the Copenhagen school of security studies. This dimension serves to explain the quadratic relationships in terms of threats.

Securitisation is an utmost stage of politisation - putting an issue so big on the political agenda that any special measures to solve it are justified. In our case, the threats to identity are securitised i.e. „presented as an existential threat, requiring emergency measures and justifying actions outside the normal bounds of political procedure" ${ }^{3}$. In securitisation analysis, the levels of securitising actors and referent objects are distinguished. The securitising actor is usually a political figure or media who start the process of securitisation move in order to make the audience believe that something needs to be protected. This "something“ is the referent object of securitisation, which can be the state, the nation, the identity.

I believe that almost all the relationships inside the quadratic model can be explained in terms of threats. Thus, the national minority can be claimed to be a threat to the national identity of post-Soviet states (host-states), the host states' activities can be considered as threatening by Russia, as they can damage the national identity of Russians in post-Soviet states and, therefore, the wider identity of Russia. The international organisations can see the situation with the minorities as a threat as well.

In this paper though, I will concentrate on Russia. As I come from the constructivist understanding of threats, I will see into the ways Russian political discourse identifies threats to Russian identity and thus state. I believe there is a close connection between the identity and the state, as they are very closely connected in Russian discourse.

What is the Russian identity then? Russians as other peoples have a myth of common descent, but it developed into a more blurred notion of Russianness, as the empire expanded, incorporating new and new ethnicities. Finally, with Sovietization and urbanization, it became even more fuzzy. Igor Zevelev stresses that „as a cultural community based on the Russian language, the Russian nation will, in a foreseeable future, remain a much broader entity than Russians living within Russian borders; yet at the same

\footnotetext{
${ }^{3}$ B. Buzan, O. Waever, J. de Wilde, Security - A New Framework for Analysis, Lynne Rienner Publishers, Boulder, London 1998, p. 24.
} 
:::: Anna Tiido, The „Russian World"...

time this same nation will continue to exclude some groups within the Russian Federation"4.

The empire has been enlarging for five centuries with a speed of 50 square kilometres a day, and the fact that this can be a good basis for Russian identity was well realised by the authorities after the annexation of the Crimea in 2014 - the expansionism works effectively for consolidation and loyalty. From the spring of 2014, Russian official discourse openly and actively exploits the images connected with the empire, expansion and "Russian glory"5.

Zevelev, to my mind rightly, suggests that the blurred boundaries of the "Russianness" lead to the multiple identities, the core of which comprise the ethnic Russians of Russia, who have little ambiguity over their national identity, the next circle are residents of Russia, who are not ethnically Russian - those two first circles comprise the civic nation of Russia (россияне). The next circle are the ethnic Russians outside Russia, and still next are those non-Russians who associate themselves with the Russian culture (for example, a Russian-speaking Ukrainian, who is a citizen of Kazakhstan). Such multi-layered identities are further complicated by intermarriages ${ }^{6}$. The census on 1989 gives for example 11.2 million people as those who speak Russian as their mother tongue, but are of a different ethnic stock (most of them lived in Belarus, Ukraine or Kazakhstan) ${ }^{7}$.

How to define „Russianness”? Sociological surveys show that „Russianness" is perceived presumably in non-ethnic definitions. Thus, in the middle of 1990s, respondents were asked what features are obvious for "Russianness". The results showed that on the first place was "love of Russia” (87\%), followed by „love of Russian culture and habits” (84\%), „Russian language” (80\%), „self-perception” (79\%), „Russian citizenship” (56\%), „signing as Russian in the passport” (51\%), „Russian parents” (one of the parents

\footnotetext{
${ }^{4}$ I. Zevelev, Russia and Its New Diasporas. United States Institute of Peace Press, Washington D. C. 2011, p. 31.

${ }^{5}$ И. Сухов, Если ты не русский, то кто?, „Независимая газета”, 16.09.2014.

${ }^{6}$ I. Zevelev, op.cit., p. 33.

7 N. Rudensky, Russian Minorities in the Newly Independent States. An International Problem in the Domestic Context of Russia Today in R. Szporluk (red.), [in:] National Identity and Ethnicity in Russia and the New States of Eurasia, M.E. Sharpe, Armonk, New York-London 1994, p. 59.
} 
or both parents) 24\%, „Russian character” (50\%), „Orthodox faith” (43\%), "Russian residents” (32\%), and "Russian appearance” (22\%) ${ }^{8}$. In the 2000s, the understanding of "Russianness” has not changed. Responding to the question who can be assumed as Russian, $41 \%$ chose the answer "those who share Russian culture”; 36\% "those who love Russia”, 29\% - „those who perceive themselves as Russians". At the same time, only $26 \%$ of the respondents considered ancestry ("Russian parents”) and 10\% - citizenship - as the main feature"

In the research by Leokadia Drobizheva the questions on identity were asked as well. „What makes you a kin with your people?” was asked, and the questionnaire included eight descriptions: „language”, „culture/habits”, „nature”, „character traits, psychology”, „religion”, „historical past”, „common state”, , appearance”. The ethnic Russians have four descriptions on the top of the list: the language, culture, nature, historical past ${ }^{10}$.

In 2013, VTSIOM published the research on the identity, where $35 \%$ of Russian residents consider as a Russian a person who grew up in Russia and was brought up in the traditions of the Russian culture. Another $14 \%$ defined Russianness through the Russian language as a mother tongue. 16\% defined Russianness through the blood (Russians by origin, by blood). 11\% consider Russians those who honestly work for the good of Russia, and 10\% choose self-identification (those who consider themselves Russians are Russians). The questions of territorial identity were also asked. According to the results, $56 \%$ of the respondents considered the Crimea as "to a large extent, it is Russia". The same number is $29 \%$ for Ukraine ${ }^{11}$.

One of the factors influencing quite a weak national identity of Russians is the fact that modern Russia stemmed from the Russian Empire first and the Soviet Union second, and the identity of the Russian nation has not

${ }^{8}$ I. Klyamkin, V. Lapkin, Русский вопрос в России [Russian issue in Russia, „POLIS”, 5 (1995), pp. 78-96; P. Panov, Nation-building in post-Soviet Russia: What kind of nationalism is produced by the Kremlin?, „Journal of Eurasian Studies” 1 (2010), Issue 2, pp. 85-94.

9 N. Tikhonova, Постимперский синдром или поиск национальной идентичности, После Империи, Liberal Mission, Moscow 2007, pp. 156-177.

10 Л. Дробижева, Социальные проблемы межнациональных отношений в постсоветской России, Центр общечеловеческих ценностей, Moscow 2003, p. 350.

11 Современная российская идентичность: измерения, вызовы, ответы, Валдай клуб, Moscow 2013. 
:::: Anna Tiido, The „Russian World"...

formed before the creation of a huge empire. One of the most important ideas preserved by the peoples after the collapse of the USSR was the idea of an empire. „We surprised, astonished and terrified the world by our empire. The life in the empire did not go without notice. It formed the consciousness, went into the culture of the Russian residents", writes Sergei Nikolski from the Institute of Philosophy of the Russian Academy of Science. He stresses that the nation-state is a different form of state. Though, it does not mean that only one ethnic group dominates over the others. In our days, nation is a super-ethnic notion manifesting the civic unity ${ }^{12}$. It is a very different perception from the small nations of the former Soviet Union, where national ethnic core of the nation is well defined.

The existence of the „diaspora” made it possible for Russia to feel like a great power and justify the possibility to act outside the Russian borders on the pretext of protecting Russians abroad. It also justified the leading role of Russia in the post-Soviet space and added to Russia's seeing itself as „a great power”. The Russian link to its diasporas allowed Russia to obtain new identity as a kin-state, as a historic homeland for the Russian communities abroad. It shows clearly how the domestic and foreign policies are interconnected ${ }^{13}$. Neil Melvin argues that the topic of settler communities, of Russian diaspora, became central in defining the new Russian national identity. As a result of internal political battle the two notions of ethnic (русский) and civic (российский) were merged together in a highly ambiguous relationship. The notion of Russian diaspora thus supported the myth of Russia as a homeland, as a great power ${ }^{14}$. Russia reinvented itself as a kinstate, a homeland, as a powerful protector.

Vladimir Putin gave the tone to the understanding of ethnic issues in his article of 2012, where he states that Russian national and migration problems are directly connected with the disintegration of the USSR and in essence of the big Russia, which formed in the $18^{\text {th }}$ century. According to Putin, the historic Russia is not an ethnic state and not the American

12 С. Никольский, Единство нации и патриотизм, „Независимая газета”, 6.10. 2014.

13 N. Melvin, Russians beyond Russia, Royal Insitute of International Affairs, London 1995, p. 7.

${ }^{14}$ Ibidem, p. 21. 
„melting pot”, where all are migrants, but a multinational state, which have developed for centuries. The kernel of this unique civilisation is the Russian people, Russian culture. Putin states that the experience of the development of the Russian state is unique, it is a multinational society, but at the same time, a single nation. It makes the country complicated and multidimensional. He continues saying that the Russian minorities abroad never formed strong diasporas, though there were plenty of Russians in numbers. He explains this fact by the idea that the Russian people is the state-forming nation. The great mission of Russians is to unite, strengthen the civilisation. He cites Fiodor Dostoevsky, naming this phenomenon „world responsiveness" (всемирная отзывчивость). According to Putin, this civilizational identity is based on the preservation of Russian cultural dominant. The carriers of this cultural dominant are not only ethnic Russians, but all carriers of this identity notwithstanding the ethnicity ${ }^{15}$.

The Crimea becomes a symbolic venue in the Russian discourse. It is connected with Orthodox Christianity, the birth of Russia. In December 2014, in his speech to the Federal Council, Putin explicitly explains the role of the Crimea in Russian history according to the vision of the authorities: „For Russia, the Crimea, ancient Korsun, Chersones, Sevastopol have an enormous civilizational and sacral meaning, the same way as the Temple Hill in Jerusalem is important for believers in Islam and Judaism. Exactly here, in Crimea, in ancient Chersones, or how the ancient Russian chroniclers called it, Korsun, the Prince Vladimir was baptized, and then he baptized the whole of Rus"16. The press cites also the chronicles of Nestor, where this event was described. By this new narrative, the story of the beginning of Russia finally got a solution. As Kyiv often claims that Rus started from Kyiv, the Russian authorities by 2014 acquired rhetoric of the Crimea as a place where Russia begins, stressing that by that time, Crimea is officially a part of the Russian state. In his speech, Putin also states that ,the historic unification with Russia of the Crimea and Sevastopol took place. For our country, this event has a special meaning, because it is our people who live in Crimea, the territory itself is strategically important, because it is here, where the spiritual

\footnotetext{
15 В. Путин, Россия: национальный вопрос., „Независимая газета”, 23.01.2012.

${ }^{16}$ Крещение Руси произошло не в Киеве, а в Севастополе, „МК.RU”, 4.12.2014.
} 
:::: Anna Tiido, The „Russian World"...

source of formation of multifaceted, but united Russian nation and centralised Russian state lies"17.

As we could see, the state and the identity of Russians are very closely connected. It leads to the situation when the blurriness of borders results in certain Russia's policies, which try to embrace all the ethnic Russians, no matter if they are residents of Russia, Russian citizens or even just people affiliated in some ways with Russia.

In foreign policy, this tendency manifests itself in the recent domination of so-called Civilizationalist approach. Andrei P. Tsygankov extensively analyses the trends in Russian policies, dividing the elite thinkers into Statists, Westernizers and Civilisationalists. Westernizers placed the emphasis on Russia's similarity with the West and viewed the West as the most viable and progressive civilization in the world. The liberal Westernizers in post-Soviet Russia argued the "natural" affinity of their country with the West based on such shared values as democracy, human rights, and a free market.

Statists, by contrast, emphasized the state's ability to govern and preserve the social and political order. For a long time, since the mid-1990s, it was the most influential school of Russia's foreign policy thinking. It is explicit in choosing values of power, stability, and sovereignty over those of freedom and democracy. Critical to Statism is the notion of external threat to Russia's security. Ever since the two-centuries long conquest by Mongols, Russians have developed a psychological complex of insecurity and a readiness to sacrifice everything for independence and sovereignty ${ }^{18}$. A statist foreign policy draws its inspiration from the often-competitive strategic requirements of the parent country and views cooperation as conditional. Its stance towards community-building is the same: it rejects neither cooperation nor community building in principle, but it judges these ventures by whether they benefit the nation. Statism typically begins with an intense focus on the internal integrity of the state. Looking outward, it seeks a secure environment that will allow the state to live safely and prosper. According-

17 В. Путин, Крым, где принял крещение князь Владимир, имеет для нас сакральное значение, „Православие.RU”, 4.12.2014.

18 A.P. Tsygankov, Russia's Foreign Policy. Change and Continuity in National Identity. Rowman and Littelfield Publishers, Inc., London 2006, p. 5. 
ly, it often aspires to dominate the areas near its borders and to exert influence further out. Statism can be imperial, but need not be so. Its outward strategic thrust has geopolitical aims, especially that of great powers worrying about their external setting and having the resources to contemplate trying to control it ${ }^{19}$.

Finally, Civilizationists have always seen Russian values as different from the West, and they have always attempted to spread Russian values abroad, outside the West. Their response to Russia's security dilemmas has been more aggressive than that of the more status quo oriented Statists. As a foreign policy philosophy, Civilizationism dates back to Ivan the Terrible's "gathering of Russian lands" after the Mongol Yoke and to the dictum „Moscow is the Third Rome“, which was also adopted under Ivan. Unlike Westernizers and Statists, Civilizationists have sought to challenge the Western system of values, insisting on the cultural superiority of Russia and Russiacentered civilization. Some representatives of this school advocated a firm commitment to values of Orthodox Christianity, while others viewed Russia as a synthesis of various religions ${ }^{20}$.

The issue of blurriness of Russianness manifests itself also in the policy directed towards Russians abroad or Compatriots.

The legal concept of compatriots comes from the Federal Law on Compatriots Abroad („The Federal Law on the State Policy of the Russian Federation in Relation to Compatriots Abroad") of 1999, which came into force on the $1^{\text {st }}$ of June of the same year. This law actually does not define precisely who a "compatriot" is. Legally speaking, a compatriot is any citizen of Tsarist Russia, Soviet Russia or Soviet Union. The compatriots are also descendants of other states' citizens who do not belong to the "titular" nation ("titular" meaning the ethnic nations of former Soviet Union non-Russian republics, the word itself means the ethnic nation present in the name of the state, e.g., France- French, Estonia- Estonian) and are presumably Russian-speaking. In the same way, anyone who feels link to Russia, consider himself or herself a compatriot - in this case, this category is not legal anymore, but ethno-psychological one. This policy as such is closely connected to securitisation, as the motif of the discourse is that of the need to protect

\footnotetext{
19 R.L. Kugler, Enlarging NATO. The Russia Factor, RAND, Santa Monica 1996, p. 25.

${ }^{20}$ A.P. Tsygankov, op.cit., p. 7
} 
:::: Anna Tiido, The „Russian World"...

compatriots. It means there is a threat. Not just the law, but Russian discourse in general, have ambiguous definitions of compatriots. After the law was in force, in 2001, Putin said that „but a compatriot is not a purely legal category. And even further - it is not a question of status or any advantages. This is, first and foremost, the question of personal choice. The question of self-determination. I would even say more precisely - of spiritual choice. This way is not always easy"21. Similar statements appeared in the media at the time from other officials. For example, Deputy Prime Minister Viktor Hristenko: „This question, as I see it, will solve by itself. The person who feels a live link to Homeland, considers himself Russian (россиянин - the one living in Russia) and keeps affiliation to the Russian language and culture - this person is our compatriot. The main thing is that the person considers himself a Russian compatriot" 22 . At the same time, one can see a contradiction. On one hand, Russia's discourse considers as compatriots those who define themselves as such. On the other hand, Russia includes all the Russian-speakers abroad as compatriots, notwithstanding their own will. There are many definitions of Russian-speaking population abroad: compatriots, Russian-speakers, Russians (русские), Russians (россияне), Russian peoples, Russian diaspora, Russian community, co-citizens, non-titular population, national minorities, non-indigenous population. In 2001, Putin signed the new document „The Concept of supporting by the Russian Federation of the compatriots abroad at the present stage", in which the notion of a "compatriot” is even blurrier. „Persons permanently living outside of Russian Federation, but connected to Russia by historic, ethnic, cultural, language and spiritual links, who strive to preserve their Russian originality (самобытность) and willing to keep contacts and cooperate with Russia"23.

Although a law defining this concept has been in force in Russia since 1999, the discussion is still ongoing. Amendments to the law were submitted for consideration to the State Duma in February 2010 with the aim of

${ }^{21}$ V. Putin, The speech on the Congress of Compatriots, 11.10.2001, http://archive. mid.ru//bdomp/dip_vest.nsf/99b2ddc4f717c733c32567370042ee43/c74b760c38b67 860c3256b290041b281!OpenDocument (acccessed: 18.07.2016).

22 A. Medvedev, Христенко из Харбина, „Росийская газета, 1.10.2001.

23 О. Самородний, Соотечественники Кремля, Kärdla 2014, p. 71. 
more precisely defining the term compatriot, stressing an individual's selfidentification and his/her practical connection with Russia. Such a connection could be, for example, membership in a Russian non-governmental organization (NGO) operating abroad ${ }^{24}$. The new edition of the law redefines the term "compatriot living abroad" in such a way that it no longer automatically applies to the persons who in the past lived in the former USSR. At the same time, the law clarifies the procedure for being recognised as a compatriot, which is based on the principle of self-determination. In addition, the Federal Law specifies the procedure for representing the interests of compatriots living abroad in government bodies of the Russian Federation, and clarifies the principles and objectives The term "compatriots living abroad" is redefined in the new edition of the Federal Law in such a way that it no longer automatically applies to all persons who in the past lived in the former USSR. At the same time, the law clarifies the procedure for being recognised as a compatriot, which is based on the principle of self-identification. In addition, the Federal Law specifies the procedure for representing the interests of compatriots living abroad in government bodies of the Russian Federation, and clarifies the principles and objectives of state policy toward compatriots living abroad, including support in the areas of culture, education and information.

The amendments specify that what is "important" is ,the fact of their free choice in favour of spiritual, cultural and legal ties with Russia," a choice that can be demonstrated by their "social or professional activity on the basis of Russian and the native languages of the peoples of the Russian Federation” or by other „evidence of [this] choice.” Dmitri Medvedev signed the Federal Law on these amendments in June, 2010.

The previous definition of the term allowed Russian foreign policy makers to consider nearly all Russian speaking residents of its neighbouring countries as a target audience for its compatriots policy. Russia's officially stated "concern" for this group allowed it to portray its active foreign policy towards the neighbouring countries as a moral obligation. In practice, this "concern" has at times been little different from interference in the other countries' internal affairs. The debate on the principles of the compatriots'

\footnotetext{
${ }^{24}$ A. Kudors, „Russian World” - Russia's Soft Power Approach to Compatriots Policy, „Russian Analytical Digest“ 2010, No. 81, p. 10.
} 
:::: Anna Tiido, The „Russian World"...

policy has a lot to do with Russia's ongoing search for identity. The multiethnic composition of the Russian population does not permit the proponents of its compatriots' policy to base their concept on ethnicity. In her study entitled "Russian diaspora and the Russian compatriots”, Marlene Laruelle, a researcher at the Central Asia-Caucasus Institute, observes that Russia's foreign policy makers were faced with the task of finding a common denominator for compatriots living abroad that would somehow combine legal, ethnic and other aspects ${ }^{25}$. In the law, there is thus a surmising solution to nation-building agenda, as the fuzzily defined "compatriots" are the "us" group of the Russian state. This designation legalises the ambiguity on the question of the nation's boundaries. This legal vagueness has served a functional purpose as it has allowed the government to pursue a broad range of policies, to quickly re-direct these policies when desired, and to target a broad range of groups in the former Soviet space ${ }^{26}$.

In essence, the Compatriot policy is a process of securitisation. The policy itself foresees extraordinary measures in order to protect Russians abroad. The protection of compatriots foresees extraordinary measures. First of all, it is financial aid to support the Russian language, education, and culture. For example, in 2001, after the Law of Compatriots came into force, the aid comprised an overall of 90,2 million roubles, it included the aid to war veterans, Russian books to schools, the teachers' training.

The instrumentalisation of the Compatriot policy can be also clearly seen in the State programmes on Compatriots. A State Programme to Work with Compatriots Living Abroad is adopted every two years. The latest two-year programme was launched on 5 July 2013. The programme involves several ministries and organizations, but the Ministry of Foreign Affairs plays a key role. The different efforts are grouped under five headings: (1) consolidating compatriot organizations, through international actions, festivals, and so on; (2) developing information for compatriots; (3) developing cultural, scientific and religious relations with compatriots, and securing Russian spiritual, cultural and linguistic ties among Russian-speakers; (4) measures to support the youth in the Russian diaspora; and 5) support for social-

${ }^{25}$ Ibidem.

26 O. Shevel, Russian Nation-building from Yel'tsin to Medvedev: Ethnic, Civic or Purposefully Ambiguous?, „Europe-Asia Studies“ 63 (2011), No. 2, p. 179. 
ly exposed sections of compatriot communities. Thus, the programme takes a broad approach to the issue of compatriots, from film festivals, to scientific seminars to medical aid. It also involves organizations such as Rossotrudnichestvo, Russkii mir, ITAR-TASS and other media enterprises ${ }^{27}$.

In 2008, the Russian Centre for International Scientific and Cultural Cooperation (RCISCC or Roszarubezhtsentr), a governmental successor of the Union of Soviet Societies for Friendship and Cultural Relations with Foreign Countries, was transformed into the Federal Agency for the Commonwealth of Independent States, Compatriots Living Abroad and International Humanitarian Cooperation (Rossotrudnichestvo). The new agency took possession of a broad network of RCISCC's foreign missions - there are currently missions in 76 countries - and was compared to USAID in its scale and new functions. In March 2012, Konstantin Kosachev, who had served as the Chairman of the State Duma Committee on Foreign Affairs for the previous seven years, was appointed as the head of Rossrotrudnichestvo.

Rossotrudnichestvo is supposed to become the coordinating centre for various kinds of Russian foreign humanitarian activity, including support for Russian compatriots living abroad, preserving Russian cultural heritage, promoting the Russian culture and language and educational and scientific cooperation. The agency is also likely to take a leading role in managing Russian international development assistance - the Concept of Russia's participation in international development assistance was approved by the President in 2007, but up to now no agency has been designated to implement it. With such an ambitious agenda, the financing and responsibilities of Rossotrudnichestvo are expected to expand accordingly.

In 2010 President Medvedev ordered the establishment of two new institutions with foreign policy goals: the Gorchakov Fund for Public Diplomacy Support and Russian International Affairs Council. The Fund for Public Diplomacy Support was named after Alexander Gorchakov - a prominent and highly respected Russian diplomat of the 19th century and schoolmate of one of the greatest Russian poets, Alexander Pushkin. Overall, this initiative was welcomed by experts, with one Russian official even calling it a „revolutionary” step aimed to improve the country's image abroad.

\footnotetext{
${ }^{27}$ M. Winnerstig, Tools of Destabilization. Russian Sof Power and Non-military Influence in the Baltic States, FOI, 2014.
} 
:::: Anna Tiido, The „Russian World"...

The Russian International Affairs Council (RIAC), which started operating in July 2011, serves as „a link between the state, expert community, business and civil society in an effort to find foreign policy solutions" ${ }^{28}$.

As the ideas of Eurasianist find their way into Russia's mainstream politics, we can see that the Civilizationalist approach becomes more and more popular. As I have above analysed the trends in the Russian policies towards minorities abroad, one cannot fail to notice that the notion of protecting compatriots have undergone a certain genesis. The closer we move to the present moment, the more one can see deeper background of the policies and even philosophical implications. I dare say that the genesis of Russia's foreign policy in general and the policy towards compatriots abroad in particular has been moving towards wider scheme, where the notion „Russian World" plays an important role.

The term „Russian World” was used in medieval accounts to define ancient Rus. It can be traced to the 11th century in the writings of Russian Grand Prince of Kiev Iziaslav Iaroslavich, who spoke of a „Kherson and Russian World" in a letter addressed to the Roman Pope Clement. The term seems to have been taken from his account in the nineteenth century by Count Sergey Uvarov (1786-1855), president of the Imperial Academy of Sciences and minister of education, famous for having crafted the tripartite emblem of the reign of tsar Nicholas I: „Autocracy, Orthodoxy, Nationality”. The term "nationality" in this context is especially important (in Russian народность), as its meaning has certain connotations as well. It refers to the notion of the community, meaning rural collecitivity with responsibility for their affairs typical of Russia. It is notable that this community is called also «мир», the same word as „world”.

It is important to note that the origins of the term „Russian World” have deep historical connotations. It is closely connected to the formation of the Russian identity as such, historically grown out of the expansion of the „Rus” and later the empire. Thus, in Russian consciousness, the so-called "gathering of the Russian lands" was very important. In historic narrative,

28 O. Shakirov, Russian Soft Power under Construction, E-International Relations, 2013, www.e-ir.info/2013/02/14/russian-soft-power-under-construction/ (accessed: 14.07.2016). 
it refers to territorial expansion of the Grand Duchy of Muscovy ${ }^{29}$. It has certain historical continuation while expansion of the empire continued. As an important example, one can note here that Catherine the Great established a medal Отторженная возвратихъ ${ }^{30}$. As we see, this discourse of the right of Russians to territorial expansion becomes used by the establishment of Putin as we go along. In a way, the discourse of the „Russian World” justifies the annexation of Crimea as well.

The current, post-Soviet term of the „Russian World” has several fathers: a biological one, Petr Shchedrovitsky, and a spiritual father, Gleb Pavlovsky, who nurtured and inspired it.

In their 1999 article, Shchedrovitsky and Efim Ostrovsky elaborated on their definition of the „Russian World”. According to them, „Over the course of the twentieth century, following tectonic historical shifts, world wars and revolutions, a Russian World was created on Earth - a network of small and large communities, thinking and speaking in Russian. It is not a secret that the territory of the Russian Federation contains only half of this Russian World. The state formation created on the territory of the Russian Federation at the turn of the 1990s did not turn out to be an adequate means for incorporating Russian society into the global historical process (....) This process of social degradation (the collapse of the Soviet Union) has been compensated by the formation, over the course of the twentieth century, of a sizeable Russian diaspora in the world." In conclusion, the article highlights the innovative character of the Russian World as a sign of a new, globalized Russia: „A Russian World in a Peaceful World (русский мир в мире миров), attracting Russians from all over the world to participate in a new global meta-project"31.

In the dual nature of the concept of the "Russian World” one can see the influence of their authors - they were at the same time interested in philosophy and history and also they were brand-makers, image-makers. The Russian World is characterized by this dual aspect: in the marketing sense,

29 S. Berger, A. Miller, Nationalizing Empires, CEU Press, Budapest-New York 2015, p. 345.

30 "Returning the lands taken away".

${ }_{31}$ M. Laruelle, The „Russian World”. Russia's Soft Power and Geopolitical Imagination, Center on Global Interests, Washington 2015. 
:::: Anna Tiido, The „Russian World”...

it is a brand for establishing Russia's voice in the chorus of nations, but it is also a vessel for a more philosophical or religious messianism, with the notion that Russia's message to the world has a universal value of salvation ${ }^{32}$.

In 2007, The Russian World Fund was established under the umbrella of the Ministries of Foreign Affairs and Education and Science. Through its foundation, the Russian World Fund carries on the ambiguity of focusing on compatriots and opening up to all those interested in supporting Russia in the world. The Fund's leadership was given to a loyal intellectual apparatchik close to Pavlovsky, Viacheslav Nikonov, the head of the Politika Foundation The Fund defines the Russian World as consisting of „not only Russians, not only Rossians, not only our compatriots in the Near and Far Abroad, émigrés and their descendants. It also includes foreign citizens, speaking Russian, studying it, and all those who are honestly interested in Russia and care for its future. (...) In forming the Russian World as a global project, Russia is creating for itself a new identity, new possibilities for effective cooperation with the rest of the world, and new incentives for its own development"33. It is noteworthy that Nikonov is the grandson of Vyacheslav Molotov, the co-signer of the ill-famous Molotov-Ribbentrop Pact in the capacity of Stalin's foreign minister at his time.

Groups active abroad focus on promotion of the Russian language, Eurasian integration and demonisation of the EU association agreements, defending human rights of compatriots, promotion of Christianity and conservative values as the core of Eurasian civilization, and on the defence of the Russian interpretation of history - particularly Second World War history, (which in Russia is seen first and foremost as the Great Patriotic War.). They serve as echo chambers for the Kremlin narrative that European values are foreign, European integration means European occupation, and the association agreements are used to lure states into NATO. They also mobilize people on to the streets for protests to undermine sovereignty and stir tensions in their countries of residence.

They target three main groups in Russia's neighbourhood: the youth, the media and the elite. When targeting the youth, the aim is to consolidate the pro-Russian youth and provide them with skills and access to Russian

\footnotetext{
32 Ibidem.

33 Ibidem.
} 
thinkers and standards of journalism and diplomacy. This is done through different fora (Seleger International, Dialogue for the Future, Balkan, Caucasus and Baltic Dialogues, Slavic Integration Forum). These fora promote Russian views on history and current events ${ }^{34}$.

The term „Russian World” is generally understood to comprise not only the Russian Diaspora itself, but also an ideological concept of Russian culture and its mission in the world. Valeri Tishkov supposes that only a few countries could create a „world": „trans-national and transcontinental community, which is united by belonging to some state and loyalty to its culture. The countries that have such a world(s) are Spain, France, China and Great Britain". Tishkov claims a unique character for the Russian world - its connection to the legacy of a supranational state with many different ethnicities and languages. The history of the Soviet period, in which he sees the promulgation of the Russian language as a tool of modernization, makes it more difficult to classify and measure "native" and "non-native" speakers among those in the post-Soviet states who are also fluent in their national language ${ }^{35}$.

The appearance of the concept of the „Russian World” let the Kremlin compatriots' policy dealers avoid the blurry term „Russian compatriot”. Starting from the summer of 2007, it became fashionable to speak about "the values and interests of the Russian world" thinking whatever one wanted under this. Moreover, there is no legal definition of the notion of the „Russian world”, and this allows to use it widely, without limits. Thus, the launching of the new concept had a certain political benefit ${ }^{36}$.

The „Russian World” concept has much in common with the civilizational discourse and promotes Russia as a unique civilisation. This approach stemmed from two main directions: the Russian Orthodox church and the neo-eurasianists. Among neo-eurasianists, it is important to mention here one of its main ideologues, Aleksandr Dugin. Though his direct involvement

${ }^{34}$ J. Lough, O. Lutzevych, P. Pomerantsev, S. Secrieru, A. Shekhovtsov, Russian Influence Abroad: Non-state Actors and Propaganda, Russia and Eurasia Programme Meeting Summury, Chatam House, Vienna 2014.

35 V. Tishkov, The Russian World - Changing Meanings and Strategies, „Carnegie Papers" 2011, No. 95, August, in O. Polegky, Changes of the Russian foreign policy discourse and concept of „Russian World”, PECOB's Papers series, 2011.

${ }^{36}$ О. Самородний, ор.cit., p. 168. 
:::: Anna Tiido, The „Russian World"...

in the forming of the authorities' agenda in Russia remains subtle, there is no doubt that his ideas are used in mainstream politics. Already in his book of 1997 („The Basics of Geopolitics”), he writes that:

"The Russian people, as different from many other peoples has been formed as a carrier of unique civilization, which has all the distinct features of original and full planetary-historic phenomenon. The Russian people is the constant, which served as an axis for creation not one, but many states: from the mosaic of the dukedoms of Eastern Slavs, Moscovite Rus, the Empire of Peter the Great and the Soviet bloc. ... The Russian people did not just provide for the ethnic base for all of these state formations, but it expressed a special civilizational idea, unlike any other. It is not the state that formed the nation. The other way around, the Russian people, the Russian nation has been experimenting in history with different types of state systems, expressing in a different way (depending on circumstances) the specificity of its unique mission. The Russian people certainly belongs to the messianic peoples. As any messianic people it has universal all-human meaning, which competes not just with other national ideas, but other forms of civilizational universalism" ${ }^{37}$.

The ambivalence of Russian identity and the blurriness of geopolitics can be also tracked back to Dugin. He claims that Russians have a stake in everything, the interests of the Russian people are not limited by the Russian ethnos, Russian empire or even the whole of Eurasia ${ }^{38}$.

By 2008, the state has taken on the same notion, which can be also called Putin's conservative agenda. Although the geography of Russia as a civilization remains imprecise, the contents of this civilization are clearly rooted in conservative values. The frequency of the term "morality” (нравственность) and of the adjective „spiritual” (духовный) in Putin's speeches has increased in recent years, especially since his return to the presidency in 2012. The Kremlin understands morality as respect for "traditional" values: the heterosexual family (non-recognition of LGBT rights); an emphasis on having children as a basis for individual life but also for the country's demographic health; the fight against alcoholism; and respect for

37 А. Дугин, Основы геополитики. Геополтическое будущее России, Арктогея, Moscow 1997, p. 189.

${ }^{38}$ Ibidem, p. 191. 
the elderly and for hierarchy ${ }^{39}$. The concept of "civilization" proved ideologically handy for the Russian authorities.

As the state took on the philosophical concept as its doctrine, one can notice how the term started to appear in the official statements. In 2001, during the first Congress of Compatriots, the term was used by Putin. Tatjana Poloskova explains it in the interview to the radio station "Golos Rossii" „we first included in the text the idea of consolidation and structuring of the foreign (зарубежный) Russian World as a basis of Russia's policy in this direction. The goal of this project is the formation of transnational network of cultural, economic, information links between the islets of the Russian diasporas" ${ }^{\prime 4}$.

The two corner stones of the "Russian World" concept are the Russian language and the Orthodox church. From a political perspective the Russian language is seen as a way of holding the Russian world together. Russian language policy is definitely directed towards the growth of the influence of the Russian language through compatriot policy. The Russian language is also a means of information. The Russian language is defined as an important object of information security. „The Russian language is the spiritual unity factor for the multi-ethnic Russian state, it is the inter-state communication language of the CIS"41.

Second cornerstones subject for unity of "Russian World” is the Russian Orthodox Church and its traditional cultural values as an alternative to the ideas of liberal democracy. Orthodox Church is at the moment also seen as a uniting bond between the three East Slavonic countries: Russia, Ukraine and Belarus (and a bit less in Moldova) .

It is interesting to note that the Church has been quite vocal in outlining the ideological background of the notion of the „Russian World”. At the Second Congress of Compatriots in 2006 in St.Petersburg, it was the metropolite Kirill who said that:

${ }^{39}$ M. Laruelle, op.cit.

40 О. Самородний, ор.cit., p. 90.

41 The Doctrine of Information Secuirty of the Russian Federation. 2000, http://archive.mid.ru//bdomp/ns-osndoc.nsf/1e5f0de28fe77fdcc32575d900298676/2deaa9ee 15ddd24bc32575d9002c442b!OpenDocument (accessed: 18.07.2016). 
:::: Anna Tiido, The „Russian World"...

„the Russian diaspora comprises not only the people by their ethnic affiliation. (...) One's belonging to the Russian diaspora also an orthodox, Muslim, Jewish or Buddhist, and people of other religions feel. (...) Russian culture is giving birth to such a multifaceted phenomenon as a Russian world. (...) In order for the persons originating from the states of historical Russia to remain part of the Russian world, it is necessary to apply all their strength to preserve their faith, a common system of values, common assessment of history, a common language. (...) Russia must firmly oppose all of those who try to tear the body of the common Russian people apart. (...) It is difficult to imagine the work with compatriots without the participation of the Russian church in it ${ }^{\prime \prime 42}$.

From the point of view of its proponents, one of the advantages of involving the Russian Orthodox Church in the compatriots' policy is that it removes the program from the purely political realm, at least to a certain extent. While the traditionally close relationship between church leaders and the secular authorities in Russia cannot be negated, those in political office may arguably reduce the likelihood and fierceness of attacks against state activities by teaming up with the church in promoting the compatriots policy. Religious freedom, highly regarded in the West, offers some degree of legitimacy to the international activities of the Russian Orthodox Church.

In reference to our to our topic, the events of 2014 are especially important. Before that, one can say that the foreign policy and national security agenda existed quite separately from the notion of the „Russian world” or rather, the concept was very much in the identity's theoretical realm. The revolution in Ukraine allowed (and from the Kremlin's perspective even forced) Russia to securitise the question of identity; that is to make it one of the issues critical for the survival of the Russian nation and statehood. On March 7, 2014, in commenting on the situation in Crimea, Dmitry Peskov, Putin's press secretary, said that the President of the Russian Federation is a guarantor of security for the Russian world. This statement reflects a fundamental change in official perception of the Kremlin's zone of responsibility in questions of security: it marks a shift in this zone from the nation-state level to the level of a community larger than a nation-state. This signals a swift securitisation of the Russian world concept ${ }^{43}$.

\footnotetext{
42 О. Самородний, op.cit., p. 138.

${ }^{43}$ I. Zevelev, op.cit.
} 
On July 2, 2014, Putin addressed the conference of the Russian ambassadors with similar themes. He stressed that Russia is entitled to protect Russian population groups abroad. The objects of such entitlement are, according to Putin „compatriots, Russian people, people of other ethnicities, their language, history, culture, their legitimate rights. When I say Russian people and Russian-speaking citizens, I mean people who sense that they are a part of the broad Russian world, not necessarily of Russian ethnicity, but everyone who feels to be a Russian person”. He warned, „I would like to make it clear to all: our country will continue to actively defend the rights of Russians, our compatriots abroad, using the entire range of available means - from political and economic to operations under international humanitarian law and the rights [of compatriots abroad] to self-defence" ${ }^{\prime 4}$.

On the basis of the analysed material, it can be claimed that the Russian official discourse securitises the minority issue indeed. It uses many arguments for the protection of the minorities with extraordinary measures. The situation is especially complicated as the referent object of the protection is deliberately left blurred and unclear. The concept of the „Russian World" is important in this context, as it allows to leave the object blurred, and to spread the idea of needed protection of the Russians far beyond the borders of Russia. The Russian policies also show that the motivation behind them is mixed - on one hand, there is genuine wish to protect the minorities on the basis of nationalist arguments - in order to preserve the huge nation of Russians. It includes in the notion of nation all the Russian compatriots abroad as well. On the other hand, there clearly exists geopolitical motivation, as the Russian authorities would like to create the sphere of influence around Russia, and the minorities are an instrument, which could help achieving these objectives.

${ }^{44}$ V. Socor, Putin Inflates „Russian World”, Claims Protection Rights, „Eurasia Daily Monitor" 11 (2014), Issue 120, https://jamestown.org/program/putin-inflates-russian-world-identity-claims-protection-rights/ (accessed: 17.07.2016). 
:::: Anna Tiido, The „Russian World”...

ANNA TIIDO

\section{„ROSYJSKI ŚWIAT": MGLISTY PRETEKST DLA OCHRONY ROSYJSKIEJ MNIEJSZOŚCI ZA GRANICA}

Celem artykułu jest analiza zjawiska określanego mianem „rosyjskiego świata” w kontekście jego roli w procesie zabezpieczania praw rosyjskiej mniejszości za granicą. Autorka w swoich badaniach wykorzystała schemat stworzony przez Rogersa Brubakera i uzupełniony następnie przez innych znawców problematyki, a także „teorię sekurytyzacji” rozwiniętą przez szkołę kopenhaską. Taka kombinacja umożliwiła pogłębione studia nad relacjami pomiędzy państwami goszczącymi, krajem pochodzenia, mniejszościami narodowymi i organizacjami międzynarodowymi. W artykule autorka skoncentrowała się przede wszystkim na przedstawieniu roli kraju pochodzenia, w analizowanym przypadku - Rosji.

\section{THE „RUSSIAN WORLD”: THE BLURRED NOTION OF PROTECTING RUSSIANS ABROAD}

The purpose of this article is to see into the ambigous phenomenon of the „Russian World" in connection to the role of this concept in securitising the Russian minorities abroad. I will look into the problem using the scheme developed by Rogers Brubaker complemented by other researchers and the securitisation theory of the Copenhagen school. This combination provides us with the valuable insight into the relationships between the host states, external national homelands, national minorities and international organisations. In this article, I will concentrate on the external national homeland, in our case, Russia. 